\title{
PERAN BADAN PERMUSYAWARATAN DESA DALAM PEMBANGUNAN DI DESA BANDAR AGUNG KECAMATAN PARENGGEAN
}

\author{
Kurjunaidi \\ Fakultas IImu Sosial dan IImu Politik Universitas PGRI Palangka Raya \\ (email: kurjunaidiupp@gmail.com) \\ Sriwidarti \\ Fakultas IImu Sosial dan IImu Politik Universitas PGRI Palangka Raya
}

\begin{abstract}
Abstrak
Penelitian ini dilaksanakan dengan tujuan untuk mengetahui fungsi Badan Permusyawaratan Desa di Desa Bandar Agung Kecamatan Parenggean serta untuk mengetahui faktor-faktor yang mempengaruhi peran dan fungsi Badan Permusyawaratan Desa dalam pelaksanaan pembangunan. Penelitian ini berlangsung kurang lebih 3 bulan dan berlokasi di Desa Bandar Agung Kecamatan Parenggean. Tipe penelitian yang digunakan adalah tipe penelitian deskriptif yaitu untuk eksplorasi dan klarafikasi mengenai suatu fenomena atau kenyataan sosial dengan menggunakan teknik pengumpulan data yang dilakukan dengan menggunakan teknik wawancara, studi dokumen, studi pustaka dan observasi.

Hasil penelitian menunjukkan Peran dan fungsi BPD dalam pembangunan di Desa Bandar Agung Kecamatan Parenggean Kabupaten Kotawaringin Timur yakni membahas dan menyepakati rancangan peraturan desa bersama kepala desa, menampung dan menyalurkan aspirasi masyarakat, serta melakukan pengawasan kinerja kepala desa, terkait dengan fungsi BPD mengenai pengawasan. Selain itu, faktor yang mempengaruhi fungsi Badan Permusyawaratan Desa dalam pelaksanaan pembangunan terdiri dari faktor pendukung yakni Tingkat pendidikan BPD dalam proses rekruitmen atau sistem pemilihan anggota BPD, masyarakat, pola hubungan kerjasama dengan pemerintah desa, serta Sosial budaya sedangkan Faktor penghambat yakni partisipasi anggota rapat yang masih kurang dan sarana atau Sekretariat BPD yang belum ada untukberkantor di Desa Bandar Agung.
\end{abstract}

\section{Kata kunci : Peran, Pembangunan Desa}

\section{Pendahuluan}

Desa merupakan daerah yang sering kali luput dari perhatian banyak orang khususnya dalam bidang pemerintahan, padahal jika di telah lebih dalam ternyata desa adalah lapis pemerintahan yang langsung bersentuhan dengan masyarakat. Sebuah pepatah menyebutkan bahwa kekuatan rantai besi terletak pada rantai yang terlemah. Jika mengibaratkan sistem pemerintahan nasional sebagai rangkaian mata rantai sistem pemerintahan mulai dari pusat,

\section{Jurnal Sociopolitico}


daerah, dan desa, maka desa merupakan mata rantai yang terlemah. Hampir segala aspek menunjukkan betapa lemahnya kedudukan dan keberadaan desa dalam konstalasi pemerintahan, padahal desalah yang menjadi pertautan terakhir pemerintahan dengan masyarakat yang akan membawanya ketujuan akhir yang telah di gariskan sebagai cita-cita bersama.

Desa merupakan cikal bakal terbentuknya masyarakat politik dan pemerintah di Indonesia. Dalam Undangundang Nomor 23 Tahun 2014 tentang Desa, disebut bahwa:

"Desa adalah desa dan desa adat atau yang di sebut dengan nama lain selanjutnya disebut desa, adalah kesatuan masyarakat hukum yang memiliki batas wilayah yang berwenang untuk mengatur dan mengurus urusan pemerintahan, kepentingan masyarakat setempat berdasarkan prakarsa masyarakat, asal usul, dan hak tradisional yang diakui dan di hormati dalam sistem pemerintahan Negara Kesatuan Republik Indonesia”.

Otonomi asli memiliki bahwa kewenangan pemerintah desa dalam menyatukan dan mengurus kepentingan masyarakat didasarkan pada asal usul dan nilai-nilai sosial budaya yang ada pada masyarakat setempat, namun harus dilaksanakan dalam prospektif administrai modern. Dalam hal ini, pemerintah desa harus menyadari hak-hak dan kewajiban yang dimilikinya untuk mampu mengatur dan mengurus kepentingan masyarakatnya berdasarkan asal usul adat istiadat yang berlaku dalam sistem pemerintahan nasional di bawah pemerintah daerah. Hal ini juga berarti bahwa pemberian kewenangan pada pemerintah desa secara umum ditujukan dalam rangka mengembalikan hak-hak asli melalui pengakuan atas keragaman yang selama ini di persatukan dengan nomenklatur desa.

Dalam rangka melaksanakan kewenangan yang dimiliki untuk mengatur dan mengurus kepentingan masyarakatnya, di desa di bentuk badan permusyawaratan desa sebagai lembaga legislasi (menetapkan peraturan pemerintah peraturan desa) dan menampung serta menyalurkan aspirasi masyarakat bersama kepala desa. Lembaga ini pada hakikatnya adalah mitra kerja pemerintah desa yang memiliki kedudukan sejajar dalam menyelenggarakan urusan pemerintah, pembangunan dan pemberdayaan masyarakat.

Disinilah kemampuan (kapabilitas) Anggota Badan Permusyawaratan Desa (BPD) diperlukan dalam menjalankan perannya. Urusan Pemerintah Desa akan berjalan dengan baik apabila terjadi kerjasama yang baik antara Aparat Desa dengan Badan Permusyawaratan Desa (BPD). Kapabilitas biasanya menunjukan potensi dan kekuatan yang ada dalam diri seseorang untuk menunjukan kemampuan dalam bidang penyelenggaraan Pemerintahan Desa, untuk itu Anggota BPD dituntut mempunyai wawasan yang luas baik pengalaman, pengetahuan, keterampilan dan sikap. Pengetahuan dan keterampilan seseorang dalam ikut terjun langsung dalam penyelenggaraan Pemerintahan Desa mempunyai pengaruh terhadap kemampuan seseorang (Anggota BPD) dalam menangani masukan dari masyarakat dan dalam pengambilan keputusan Desa sehingga keputusan yang diambil sesuai dengan keinginan dan aspirasi dari masyarakat.

Para anggota BPD tidak terlalu memahami peran dan fungsinya di desa sehingga mengakibatan kurang maksimalnya peran serta dan dukungan

\section{Jurnal Sociopolitico}


dari Badan Permusyawaratan Desa (BPD) sebagai lembaga yang diperlukan untuk membantu Pemerintahan Desa dibidang pembangunan dalam menyerap aspirasi masyarakat. Hal ini mengakibatkan banyak aspirasi masyarakat yang tidak mampu terserap yang berdampak pada tingkat pembangunan yang berjalan lamban. Kendala utamanya adalah terbatasnya tingkat kemampuan para Anggota Badan Permusyawaratan Desa (BPD), sehingga para Anggota BPD belum mampu menjalankan perannya secara maksimal. Ini terlihat dari adanya beberapa Anggota Badan Permusyawaratan Desa (BPD) yang jarang mengikuti rapat-rapat baik dalam pembahasan rencana pembangunan, pelaksanaan pembangunan maupun rapatrapat evaluasi hasil pembangunan, disamping itu masih didasarkan kurang efektifnya jalinan komunikasi antara Anggota Badan Permusyawaratan Desa (BPD) dengan Aparat Desa sehingga informasi pembangunan terkadang tidak akurat, tidak meratanya pengetahuan dan wawasan yang dimiliki oleh Anggota BPD sehingga terjadi perbedaan dalam melihat dan memahami suatu persoalan. Berdasarkan beberapa uraian tersebut menunjukan rendahnya peran Anggota Badan Permusyawaratan Desa (BPD) terhadap pembangunan sehingga, peran utama dari BPD yaitu mengayomi, legislasi, pengawasan dan menampung aspirasi masyarakat kurang dapat berjalan sesuai dengan harapan. Seharusnya sejalan dengan tugas dan fungsinya Badan Permusyawaratan Desa (BPD) yang sangat berperan dalam menentukan keberhasilan penyelenggaraan Pemerintahan Desa, pembangunan desa serta pembinaan masyarakat desa, maka para Anggota Badan Permusyawaratan Desa (BPD) harus memiliki tingkat pengetahuan dan wawasan yang sesuai dan lebih baik, sehingga tingkat keberhasilan pembangunan dapat dicapai dengan maksimal. Untuk mengkaji lebih jauh tentang Peran Badan Permusyawaratan Desa, maka penulis mengangkat judul penelitian tentang "Peran Badan Permusyawaratan Desa Dalam Pembangunan Di Desa Bandar Agung Kecamatan Parenggean".

\section{Metode Penelitian}

Dasar penelitian adalah observasi mendalam yaitu metode pengumpulan data dengan terjun langsung ke lapangan untuk mengumpulkan data-data dan fakta-fakta baik melalui wawancara langsung ataupun melalui pengamatan terhadap kondisikondisi yang berhubungan dengan obyek penelitian.

Tipe penelitian yang digunakan adalah deskriptif, yaitu dimaksudkan untuk eksplorasi dan klarifikasi mengenai suatu fenomena atau kenyataan sosial, dengan jalan mendeskripsikan data dan fakta yang berkenan dengan masalah dan unit yang diteliti. Dalam penelitian ini bertujuan memberikan gambaran secara jelas tentang peran badan permusyawaratan desa dalam pembangunan desa.

\section{Hasil dan Pembahasan}

\section{Peran BPD Dalam Pembangunan di Desa Bandar Agung}

Dalam strukur Pemerintahan Desa, kedudukan Badan Permusyawaratan Desa ( BPD ) adalah sejajar dengan unsur Pemerintah Desa bahkan mitra kerja dari Kepala Desa, hal tersebut dimaksudkan agar terjadi proses penyeimbang

\section{Jurnal Sociopolitico}


kekuasaan sehingga tidak terdapat saling curiga antara Kepala Desa dan BPD sebagai Lembaga Legislasi yang berfungsi mengayomi adat istiadat, fungsi pengawasan dan fungsi menampung dan menyalurkan aspirasi masyarakat.

Disinilah kemampuan (kapabilitas) Anggota Badan Permusyawaratan Desa (BPD) diperlukan dalam menjalankan perannya. Urusan Pemerintah Desa akan berjalan dengan baik apabila terjadi kerjasama yang baik antara Aparat Desa dengan Badan Permusyawaratan Desa (BPD). Kapabilitas biasanya menunjukan potensi dan kekuatan yang ada dalam diri seseorang untuk menunjukan kemampuan dalam bidang penyelenggaraan untuk itu Anggota BPD dituntut mempunyai wawasan yang luas baik pengalaman, pengetahuan, keterampilan dan sikap.

Pengetahuan dan keterampilan seseorang dalam ikut terjun langsung dalam penyelenggaraan Pemerintahan Desa mempunyai pengaruh terhadap kemampuan seseorang (Anggota BPD) dalam menangani masukan (input) dari masyarakat dan dalam pengambilan keputusan Desa sehingga keputusan yang diambil sesuai dengan keinginan dan aspirasi dari masyarakat.

Kehadiran

Badan

Permusyawaratan Desa dalam Pemerintahan Desa dengan berbagai fungsi dan kewenangannya diharapkan mampu mewujudkan sistem check and balance dalam pemerintahan desa. Sebagai perwujudan demokrasi, dalam penyelenggaraan pemerintahan desa, Kepala Desa dan Badan Permusyawaratan Desa (BPD) bekerja sama dalam mengurus dan mengatur kepentingan masyarakat setempat berdasarkan asal-usul dan adat istiadat setempat yang diakui dan di hormati.
Dalam pengimplementasian fungsi Badan Permusyawaratan Desa (BPD) sebagai badan legislatif desa dan wadah aspirasi masyarakat diharapkan dapat tercapai dengan baik dan efektif. Dengan kata lain pemerintah desa dan Badan Permusyawaratan Desa (BPD) dapat bersinergi dengan baik dalam menyelenggarakan pemerintahan tentunya dengan mendapat dukungan darimasyarakat.

\section{Membahas dan menyepakati rancangan peraturan desa bersama Kepala Desa}

Peraturan desa adalah produk hukum tertinggi yang di keluarkanpemerintah desa yang bersifat mengatur, yang di buat baik oleh usul kepala desa maupun usul Badan Permusyawaratan Desa (BPD) yang disetujui bersama dan di tetapkan oleh kepala desa dan di umumkan dalam berita desa yang dibuat baik sebagai pelaksanaan/penjabaran peraturan perundang-undangan yang lebih tinggi maupun untuk penyelenggaraan pemerintahan desa. Perumusan Peraturan desa layaknya dilaksanakan melalui mekanisme sebagai berikut:

1. Rancangan peraturan desa baik yang disiapkan oleh Badan Permusyawaratan Desa (BPD) maupun oleh Kepala Desa, disampaikan oleh pimpinan BPD kepada seluruh anggota BPD selambat-lambatnya tujuh hari sebelum rancangan peraturan desa tersebut di bahas dalam rapat paripurna.

2. Pembahasan rancangan kepala desa dilakukan oleh BPD bersama kepala desa.

\section{Jurnal Sociopolitico}


3. Rancangan dapat ditarik kembali sebelum dibahas bersama oleh BPD dan kepala desa.

4. Rancangan peraturan desa yang telah disetujui bersama BPD dengan Kepala desa disampaikan oleh pimpinan BPD kepada desa untuk di tetapkan menjadi peraturan desa dalam jangka waktu paling lambat tujuh hari terhitung tanggal penetapan bersama.

5. Rancangan Peraturan desa tidak boleh bertentangan dengan kepentingan umum dan peraturan perundangundangan yang lebih tinggi.

6. Peraturan desa berlaku setelah diundangkan dalam berita desa.

Dalam pembuatan peraturan desa maka terlebih dahulu dilihat dari apa saja yang menjadi aspirasi masyarakat dan apa saja yang menjadi kebutuhan di desa Bandar Agung. Kemudian dari aspirasi masyarakat yang disampaikan itu kembali di rapatkan oleh BPD dalam rapat internal BPD apakah aspirasi maasyarakat ini perlu di perdeskan atau tidak kemudian disampaikan dalam rapat bersama kepala desa.

Adapun Mekanisme dalam menetapakan peraturan desa adalah beberapa tahap atau langkah-langkah yang ditempuh oleh BPD dalam menetapkan Peraturan Desa yaitu menampung usulanusulan baik yang berasal dari BPD maupun Kepala Desa dimana usulan tersebut dapat menjadi dasar atau patokan dalam menjalankan Pemerintahan Desa. Setelah itu, usulan tersebut dibahas dan dievaluasi, terhadap hasil evaluas itersebut kemudian dilakukan penetapan bersama dalam bentuk rancangan untuk selanjutnya dirumuskan dalam bentuk Peraturan Desa.

$$
\text { Dalam tahap pembentukan }
$$

Peraturan Desa, gagasan atau usulanusulan lebih banyak berasal dari Kepala
Desa dibandingkan dari pihak BPD. Hal ini dikarenakan faktor pengetahuan dan wawasan BPD yang dirasa masih minim dan juga karena Kepala Desa yang terpilih sudah lebih mengetahui tentang keadaan dan kondisi desa tersebut. Proses pembuatan Peraturan Desa mulai dari merumuskan peraturan desa sampai pada tahap menetapkan Peraturan Desa yang dilakukan bersama-sama dengan pemerintah desa, tidak ada kendala ataupun hambatan berarti yang dijumpai. Berdasarkan pernyataan ketua BPD desa Bandar Agung bapak Nur Eko Siswandoyo bahwa :

"Selama ini peran keaktifan BPD dalam membahas dan menyepakati rancangan peraturan Desa sangat baik, karena dalamrapat pembahasan rancangan peraturan desa selalu dihadiri oleh pihak BPD. Pihak BPD sendiri sering melakukan rapat internal BPD terlebih dahulu apa yang mau Perdeskan dan berpaju pada apa yang menjadi kebutuhan di desa Bandar Agung.

Senada dengan apa yang diungkapkan oleh bapak Slamet Harianto selaku Kepala Desa Bandar Agung bahwa

"Peran BPD di Desa Bandar Agung sudah cukup baik karena anggota BPD terlibat dalam membahas dan menyepakati rancangan peraturan desa. Namun ada beberapa yang perlu di perhatikan oleh pemerintah Desa Maupun Kecamatan Sebaiknya ada pelatihan Khusus BPD bagaimana tata cara pembuatan perdes, sehingga semua anggota BPD

\section{Jurnal Sociopolitico}


mengetahui tata cara pembuatan perdes.

Berdasarkan hasil wawancara tersebut dan pengamatan di lapangan maka penulis dapat menyimpulkan bahwa seringnya BPD melakukan pembahasan dan menyepakati rancangan peraturan serta keaktifannya dalam pembahasan tesebut telah membuktikan bahwa pelaksanaan fungsi BPD sudah sangan berjalan dengan baik.

Masyarakat desa Bandar Agung merupakan masyarakat yang memiliki kompleksitas kebutuhan. Sejalan dengan hal tersebut mereka membutuhkan pelayanan yang berkualitas dari pemerintahan desa setempat yang harus senantiasa berusaha meningkatkan kemampuan mereka untuk memberikan pelayanan yang semakin baik sesuai tuntunan masyarakat. Salah satu tupoksi dari Badan Permusyawaratan Desa yaitu menampung dan menyalurkan aspirasi masyarakat. Badan Permusyawartan Desa (BPD) sebagai wakil rakyat di desa adalah sebagai tempat bagi masyarakat desa untuk menyampaikan aspirasinya dan untuk menampung segala keluhan-keluhan dan kemudian menindaklanjuti aspirasi tersebut untuk disampaikan kepada instansi atau lembaga terkait. Untuk itu dibutuhkan pengetahuan oleh masyarakat tentang keberadaan dan peranan BPD.

Setelah suatu Peraturan desa ditetapkan, selanjutnya peraturan tersebut diserahkan kepala desa kepada Bupati melalui Camat sebagai bahan pengawasan dan pembinaan. Kemudian untuk menindaklanjuti peraturan tersebut Kepala Desa kemudian menetapkan Peraturan Kepala desa atau Keputusan Kepala Desa yang berfungsi sebagai petunjuk teknis pelaksanaan di lapangan.
Selain itu, hal yang sama juga disampaikan oleh bapak Arifin selaku Kasi Pemdes Desa Bandar Agung yakni :

"Sebagai sekretaris desa, hal yang saya lakukan setelah rapat bersama kepala desa dan BPD yakni sebagai pelaksana teknis, dimana dalam pelaksanaan tugas selalu berkoordinasi dan selalu menindaklanjuti semua hasil dari rapat yang telah dilakukan salah satu contoh hasil dari rapat pembahasan dan rancangan peraturan desa,pembangunan, maupun hasi rapat lainnya yang berkaitan dengan desa".

Hal tersebut senada yang di ungkapkan oleh bapak M. Bisri Musthofa selaku sekretaris BPD Desa Bandar Agung yakni:

"saya selaku Sekretaris BPD selalu berkordinasi bersama sekretaris Desa mengenai hasil rapat dalam pembahasan rancangan peraturan desa dan hasil kordinasi itu saya sampaikan kepada seluruh anggota BPD dalam rapat internal BPD".

Berdasarkan hasil wawancara tersebut, dapat disimpulkan bahwa selalu adanya koordinasi yang dilakukan oleh pemerintah desa dalam hal ini kepala desa dan Kasi Pemdes Desa dengan pihak BPD dalam proses pembahasan dan pembuatan rancangan peraturan desa.

Secara konseptual, keterkaitan antara kepala desa dan Badan Permusyawaratan Desa (BPD) lebih pada check and balance yang mana pada intinya merupakan suatu mekanisme saling control di antara lembaga desa demi menghindari terjadinya penyimpangan kekuasaan dalam rangka kesejahteraan masyarakat. Dalam persfektif pembagian

\section{Jurnal Sociopolitico}


kekuasaan Badan Permusyawaratan Desa (BPD) merupakan badan legislatif desa yang berfungsi sebagai pembuat peraturan desa, wadah bagi aspirasi masyarakat dan juga mengawasi pelaksanaan peraturan desa dalam rangka pemantapan pelaksanaan kinerja Pemerintah Desa sedangkan Kepala Desa merupakan Badan Eksekutif yang berfungsi sebagai pelaksana peraturan desa.

\section{Menampung dan menyalurkan aspirasi masyarakat}

Penyelenggaraan pemerintahan desa agar mampu menggerakkan masyarakat untuk berpartisipasi dalam pembangunan dan penyelenggaraan administrasi desa, maka setiap keputusan yang di ambil harus berdasarkan atas musyawarah untuk mencapai mufakat.

Badan Permusyawaratan Desa (BPD) merupakan wadah bagi aspirasi masyarakat desa. Wadah aspirasi dapat di artikan sebagai tempat dimana keinginan atau aspirasi masyarakat di sampaikan, ditampung kemudian disalurkan. Berdasarkan hasil observasi dan penelitian penulis, tugas dan wewenang BPD dalam menggali, menampung dan menyalurkan aspirasi masyarakat telah berjalan sesuai dengan tugas dan wewenang yang ada pada peraturan daerah. Beberapa contoh keluhan- keluhan yang disampaikan oleh masyarakat kepada BPD desa Bandar Agung khususnya dalam bidang pembangunan, yaitu :

a. Masalah Irigasi

b. Rehabilitasi bangunan pasar

c. Renovasi Kantor Desa

d. Perbaikan bangunan posyandu

e. Pembangunan akses jalan Tani

f. Perabatan jalak rusak

g. Pengecoran di jalan Bandar Agung

Setelah aspirasi masyarakat desa ditampung, maka langkah selanjutnya adalah BPD menyalurkan aspirasi masyarakat tersebut dalam pertemuanpertemuan yang diselenggarakan oleh BPD. Setelah memperoleh aspirasi dan kemudian membahasnya, badan permusyawaratan desa (BPD) kemudian meneruskan dan menyampaikan sebagaimana maksud yang diharapkan oleh masyarakat. Namun pada kesempatan ini pihak pemerintah desa tetap diberi kesempatan untuk memberikan penjelasan atas aspirasi yang disampaikan oleh masyarakat. Hal tersebut menggambarkan bahwa kepala desa dan Badan Permusyawaratan Desa telah dipercaya dan ditokohkan oleh warga.

Hal tersebut di atas sejalan dengan wewenang Badan Permusyawaratan Desa (BPD) yaitu menggali, menampung, menghimpun, merumuskan dan menyalurkan aspirasi masyarakat.

Menurut bapak Eman salah satu Tokoh Masyarakat Desa

Bandar Agung mengatakan bahwa :

"BPD dalam hal ini menurut saya, sangat berperan aktif Karena Hampir $80 \%$ aspirasi masyarakat diterima oleh BPD Dalam hal pembangunan serta perlunya peningkatan dan pelestarian budaya oleh pemerintah desa dan seringnya BPD menjadi wadah masyarakat dalam menyampaikan aspirasi mereka tentang pembangunan desa."

Namun hal yang berbeda yang di kemukakan oleh Sutrisno Selaku Tokoh pemuda desa Bandar Agung bahwa :

tidak pernahnya tokoh pemuda dilibatkan dalam diskusi yang membahas mengenai kondisi desa Bandar Agung serta aspirasi dari pemuda selalu diabaikan oleh

\section{Jurnal Sociopolitico}


pihak BPD dalam hal Pembinaandan pemberdayaan pemuda desa Bandar Agung”.

Berdasarkan hasil wawancara tersebut, bahwa peran BPD dalam hal ini sebagai penampung aspirasi masyarakat telah terlaksana dengan baik sesuai dengan yang diharapkan dalam hal pembangunan . Hal tersebut dapat terlihat dari seringnya BPD menjadi wadah masyarakat dalam menyampaikan aspirasi mereka tentang pembangunan desa. disisi lain BPD menurut pengamatan serta hasil wawancara saya bahwa dalam hal menampung aspirasi lemah di kalangan Pemuda karena yang saya dapat di lapangan bahwa BPD dan pemerintah Desa kurang maksimal dalam menampung aspirasi salah satu buktinya yaitu mengenai pembinaan keolahragaan serta tidak pernahnya dilibatkan tokoh pemuda dalam dalam hal membahas kondisi desa Bandar Agung kedepannya.

Adapun data yang saya dapat dilapangan bahwa BPD ketika di undang dalam kegiatan- Kegiatan Pemuda seperti contohnya membahas kondisi desa kedepan, pembinaan pemuda, pemberdayaan pemuda maupun masyarakat, serta membahas pertanian berkelanjutan yang ada di desa Bandar Agung anggota BPD tidak hadir dikarenakan kesibukannya masing-masing anggota BPD.

Badan permusyawaratan Desa (BPD) sebagai wakil rakyat di desa adalah sebagai tempat bagi masyarakat untuk menampung segala keluhan-keluhannya dan kemudian menindaklanjuti aspirasi tersebut untuk disampaikan kepada instansi atau lembaga yang terkait. Banyak cara yang dilakukan untuk menampung segala keluhan-keluhan yang kemudian ditindaklanjuti yaitu dengan cara tertulis dan secara lisan. Cara tertulis misalnya masalah-masalah tersebut terkait dengan pembangunan dan kemajuan desa maka akan dibahas dan dibicarakan lebih lanjut dalam bentuk peraturan-peraturan desa, dan dengan cara lisan yaitu masyarakat menyampaikan aspirasinya langsung kepada BPD pada saat ada pertemuan desa atau rembug desa dan ketika ada rapat BPD.

Selain itu, hal lain yang dilakukan oleh BPD dalam meningkatakan pembangunan desa yakni dengan selalu melihat situasi dan kondisi lapangan tanpa menunggu adanya keluhan dari masyarakat serta melakukan musyawarah evaluasi dalam bidang pembangunan setiap bulannya.

Seperti yang disampaikan oleh bapak Harijoto selaku anggota BPD, bahwa :

"Setiap bulan selalu diadakan musyawarah evaluasi dalam bidang pembangunan yang disarankan serta BPD selalu melihat situasi dan kondisi di lapangan tanpa menungguadanya keluhan atau Masukan dari masyarakat mengenai pelaksanaan pembangunan."

Setelah aspirasi masyarakat desa ditampung, maka langkah selanjutnya adalah Badan Permusyawaratan Desa (BPD) menyalurkan aspirasi masyarakat tersebut dalam pertemuan-pertemuan yang diselenggarakan oleh Badan Permusyawaratan Desa (BPD).

Setelah memperoleh dan kemudian membahasnya,badan Permusyawaratan Desa (BPD) kemudian meneruskan dan menyampaikan sebagaimana maksud yang diharapkan oleh masyarakat.

\section{Jurnal Sociopolitico}


Namun pada kesempatan ini pihak pemerintah desa tetap di beri kesempatan untik memberikan penjelasan atas aspirasi yang disampaikan oleh masyarakat.

Berikut ini pernyataan Ibu Mujiburroman selaku Kaur Umum dan Perencanaan Desa Bandar Agung yakni :

"Beberapa hal yang menjadi perhatian pemerintah dalampembangunan desa yakni, perlunya perbaikan atau renovasi posyandu, pembangunan pasar, pembangunan irigasi, pembangunan jalan, selain itu perlu ada pembangunanposkamling di tiap RT agar tercipta keamanan di tiap RT.

Dari hasil wawancara tersebut, maka hal yang menjadi perhatian khusus pemerintah dalam bidang perencanaan pembangunan saat ini yaitu peningkatan dalam bidang pertanian dan kesehatan. Serta Masyarakat desa Bandar Agung masih membutuhkan banyak tindak lanjut pemerintah dalam hal pembangunan pasar, penataan lapangan olahrahga serta penambahan bangunan poskamling di tiap RT.

\section{Melakukan pengawasan kinerja kepala desa}

Kepala Desa di dalam melaksanakan pemerintah desa juga berhak untuk membuat keputusan Kepala Desa. Keputusan Kepala Desa dibuat untuk mempermudah jalannya Peraturan Desa. Dari data yang diperoleh dari kantor Kepala Desa, ada beberapa keputusan yang telah dikeluarkan oleh Kepala Desa antara lain adalah keputusan Kepala Desa tentang Penyusunan Program Kerja Tahunan Kepala Desa yang dijadikan pedoman penyusunan Rencana Anggaran
Penerimaan dan Pengeluaran Keuangan Desa (RAPBDes) Desa.

Pengawasan yang dilakukan oleh Badan Permusyawaratan Desa terhadap keputusan Kepala Desa yaitu sebagai berikut:

a) Melihat proses pembuatan keputusan dan isi keputusan tersebut.

b) Melihat apakah isi keputusan tersebut sudah sesuai untuk dijadikan pedoman penyusunan RAPBDes.

c) Mengawasi apakah keputusan tersebut benar-benar dijalankan atau tidak.

d) Mengawasi apakah dalam menjalankan keputusan tersebut ada penyelewengan.

e) Menindaklanjuti apabila dalam menjalankan keputusan tersebut ada penyelewengan.

Fungsi sebagai pengawas BPD dituntut lebih professional dan lebihmemahami sistem pemerintah dan alur organisasi dalam desa tersebut. Berikut pernyataan Ibu Maisaroh Sekretaris BPD yang mengatakan bahwa :

"Koordinasi antara masyarakat, pemerintah dan BPD berjalan lancar tanpa menemui kendala yang berarti. BPD selalu ikut berperan dalam pengawasan terhadap kinerja kepala desa. ini di buktikan dengan sering di adakannyarapat evaluasi kinerja kepala desa per-3 bulan dalam setahun."

Hal senada dikatakan Bapak Bahtiar selaku kepala RT bahwa :

"pola hubungan antara masyarakat, pemerintah, dan BPD sudah berjalan baik karena BPD berperan aktif bersama kepal desa dalam hal pengawasan pembangunan".

\section{Jurnal Sociopolitico}


Dari hasil wawancara tersebut, dapat disimpulkan bahwa terkait dengan fungsi BPD mengenai pengawasan dapat dikatakan telah berjalan secara maksimal dengan melihat tidak adanya kendala yang dihadapi oleh BPD dalam proses pengawasan yang dilakukan tersebut. Dan peran BPD dalam hal pengawasan sudah maksimal di karenakan dala hal mengawasi kinerja kepala desa BPD mengadakan rapat evaluasi kinerja kepala desa per-3 bulan dalam setahun dengan melibatkan para tokoh masyarakat di desa Bandar Agung.

Untuk

mensejahterahkan masyarakat desa, masing-masing unsur pemerintahan desa, dan BPD, dapat menjalankan tugas dan fungsinya dengan mendapat dukungan dari masyarakat. Di dalam pelaksanaan peraturan desa, Badan Permusyawaratan Desa (BPD) juga melaksanakan kontrol atau pengawasan terhadap peraturanperaturan desa dan Peraturan Kepala Desa.

Pelaksanaan pengawasan Peraturan Desa dan Peraturan Kepala Desa yang dimaksud disini yaitu Pelaksanaan pengawasan terhadap APBDes dan RPJMDes yang dijadikan sebagai peraturan desa dan juga pengawasan terhadap keputusan Kepala Desa. Pelaksanaan pengawasan yang dilakukan oleh BPD Desa Bandar Agung Kecamatan Parenggean Kabupaten Kotawaringin Timur, adalah sebagai berikut :

1. Pengawasan terhadap Pelaksanaan Peraturan Desa.

Badan Permusyawaratan Desa dalam menjalankan fungsinya mengawasi peraturan desa dalam hal ini yaitu mengawasi segala tindakan yang dilakukan oleh pemerintah desa. Segala bentuk tindakan pemerintah desa, selalu dipantau dan diawasi oleh pihak BPD baik secara langsung ataupun tidak langsung, hal ini dilakukan untuk melihat apakah terjadi penyimpangan peraturan atau tidak.

Beberapa cara pengawasan yang dilakukan oleh BPD Desa Bandar Agung terhadap pelaksanaan peraturan desa, antara lain :

a. Mengawasi semua tindakan yang dilakukan oleh pelaksana peraturan desa.

b. Jika terjadi penyelewengan, BPD memberikan teguran untuk pertama kali secara kekeluargaan. BPD akan mengklarifikasi dalam rapat desa yang dipimpin oleh Ketua BPD

c. BPD akan mengklarifikasi dalam rapat desa yang dipimpin oleh Ketua BPD.

d. Jika terjadi tindakan yang sangat sulit untuk dipecahkan, maka BPD akan memberikan sanksi atau peringatan sesuai yang telah diatur di dalam peraturan seperti melaporkan kepada Camat serta Bupati untuk ditindaklanjuti.

Data yang saya dapat dilapangan mengenai pengawasan BPD terhadap pelaksana peraturan desa yaitu ketidak konsistenannya tentang peraturan desa dalam hal lingkungan yaitu mengenai penyemprotan rumput dan masih dilakukan masih saja dilakukan oleh masyarakat dan perdes ini di indahkan oleh BPD.

Data selanjutnya yang saya dapat di lapangan yaitu mengenai pengawasan terhadap kinerja kepala desa dalam hal ini BPD dimana dalam pelaksanaan pengawasan BPD sudah terrlihat karena seringnya BPD menegur Kepala Desa ketika melakukan tindakan sepihak atau penyelewangan salah satu contohnya dalam penerbitan SK perpanjangan masa jabatan Kepala RT tanpa sepengetahuan BPD dan tokoh masyarakat sehingga BPD

\section{Jurnal Sociopolitico}


langsung memberi teguran kepada kepala desa secara kekeluargaan.

2. Pengawasan terhadap Anggaran Pendapatan dan Belanja Desa.

Pengawasan terhadap APBDes ini dapat dilihat dalam laporan pertanggung jawaban Kepala Desa setiap akhir tahun anggaran. Adapun bentuk pengawasan yang dilakukan oleh BPD yaitu :

a) Memantau semua pemasukan dan pengeluaran kas desa.

b) Memantau secara rutin mengenai dana-dana swadaya yang digunakan untuk pembangunan desa.

BPD melakukan pengawasan terhadap jalannya peraturan desa di masyarakat. Adapun hal-hal yang dilakukan oleh BPD terhadap penyimpangan peraturan yaitu memberikan teguran-teguran secara langsung ataupun arahan-arahan. Apabila hal tersebut tidak dapat diselesaikan, maka BPD akan membahas masalah ini bersama dengan pemerintah desa dan tokoh-tokoh masyarakat lainnya.

Faktor-faktor yang mempengaruhi fungsi Badan Permusyawaratan Desa dalam pelaksanaan pembangunan.

Untuk mewujudkan suatu organisasi yang efektif dalam pelaksanaan fungsinya tidak lepas dari berbagai faktor yang mempengaruhi kinerjanya dalam mencapai tujuan. Seperti halnya dengan Badan Permusyawaratan Desa, untuk menjadi efektif tidak serta merta terjadi begitu saja tetapi ada beberapa faktor yang mempengaruhinya. Berdasarkan data yang diperoleh di lapangan terdapat beberapa faktor yang mempengaruhi efektivitas pelaksanaan fungsi BPD yaitu :

\section{a. Tingkat pendidikan anggota BPD}

Tingkat pendidikan merupakan salah satu faktor yang dapat mempengaruhi berjalannya roda pemerintahan dalam hal ini pemilihan anngota BPD.

Berdasarkan hasil penelitian menunjukkan bahwa tingkat pendidikan anggota BPD sangat mendukung dalam pelaksanaan peran dan fungsi BPD sehingga sistem rekruitmen/pemilihan anggota Badan Permusyawaratan Desa (BPD) menggunakan sistem pemilihan langsung oleh perwakilan masyarakat di tiap RT. Hal ini menjadikan tingginya kepercayaan masyarakat terhadap orangorang yang menjadi anggota BPD. Karena orang-orang yang terpilih merupakan pilihan masyarakat yang telah diketahui dan dapat diukur kemampuan dan kapabilitas yang dimiliki serta dengan pemilihan langsung oleh masyarakat dapat dipastikan tidak adanya nepotisme yang dilakukan oleh pemerintah yang terkait.

\section{b. Masyarakat}

Masyarakat, merupakan faktor penentu keberhasilan BPD dalam melaksanakan fungsinya, besarnya dukungan serta penghargaan dari masyarakat kepada BPD menjadikan BPD lebih mempunyai ruang gerak untuk dapat melaksanakan fungsinya. Dukungan dari masyarakat tidak hanya pada banyaknya aspirasi yang masuk juga dari pelaksanaan suatu perdes. Kemauan dan semangat dari masyarakatlah yang menjadikan segala keputusan dari BPD dan Pemerintah Desa menjadi mudah untuk dilaksanakan. Partisipasi masyarakat baik dalam bentuk aspirasi maupun dalam pelaksanaan suatu keputusan sangat menentukan fungsi BPD.

Dalam mewujudkan suatu organisasi yang efektif dalam pelaksanaan fungsinya tidak lepas dari berbagai faktor yang mempengaruhi kinerjanya Tidak semua keputusan yang ditetapkan oleh BPD dan Pemerintah Desa dapat diterima

\section{Jurnal Sociopolitico}


oleh seluruh masyarakat. Beberapa kebijakan yang dikeluarkan terkadang mendapat respon yang beraneka ragam baik pro maupun kontra dari masyarakat. Adanya tanggapan yang bersifat kontra tentunya dapat menghambat langkah BPD dan Pemerintah Desa dalam pelaksanaan kebijakan tersebut.

Dalam mencapai tujuan mensejahterahkan masyarakat desa, masing-masing unsur pemerintahan desa, Pemerintah Desa dan BPD, dapat menjalankan fungsinya dengan mendapat dukungan dari masyarakat. Layak tidaknya orang-orang yang menjadi anggota BPD ditentukan dari besar kecilnya dukungan yang diperoleh dari masyarakat.

\section{c. Sosial Budaya}

Gaya hidup masyarakat desa Bandar Agung yang masih sangat kental dengan budaya saling menghargai memberi pengaruh positif terhadap efektifitas implementasi fungsi BPD. Masyarakat desa Bandar Agung masih sangat menjunjung tinggi budaya menghormati orang yang lebih tua dan menghargai orang yang lebih muda sehingga rasa kekeluargaan lebih diutamakan antara mereka. Pihak BPD dengan pemerintah desa senantiasa menjadikan hal tersebut sebagai landasan untuk meminimalisir jika terjadi perbedaan-perbedaan antar masyarakat yang dapat menimbulkan potensi konflik.

\section{d. Pola hubungan kerjasama antara BPD dengan pemerintah desa.}

Salah satu faktor pendukung efektivitas tugas dan fungsi BPD adalah terciptanya hubungan yang harmonis antara BPD dengan Pemerintah Desa dengan senantiasa menghargai dan menghormati satu sama lain, serta adannya niat baik untuk saling membantu dan saling mengingatkan. Keharmonisan ini desa sebabkan karena adanya tujuan dan kepentingan bersama yang ingin dicapai yaitu untuk mensejahterakan masyarakat desa. Sebagai unsur yang bermitra dalam penyelenggaraan pemerintahan desa, BPD dan Pemerintah Desa selalu menyadari adanya kedudukan yang sejajar antara keduanya.

Hal ini di kemukan oleh Kasi Pemdes desa bapak Arifin bahwa :

"Pola hubungan anatara masyarakat, pemerintah, dan BPD sudah berjalan baik karena BPD berperan aktif bersama kepala desa dalam hal pelaksanaan pemerintahan desa".

Sesuai dengan hasil wawancara dan pengamatan saya di lapangan bahwa pola hubungan kerjasama antara pemerintah desa dengan BPD sudah terlaksana dengan baik karena ketika ada masukan dari masyarakat ke kepala desa maka segera menyampaikan apa yang menjadi masukan masyarakat ke BPD begitupun sebaliknya. Dan Kepala Desa selalu berkordinasi ke BPD mengenai masukan dari masyarakat mengenai pembangunan Desa serta BPD dan Kepala Desa berperan aktif dalam mewujudkan program dari bawah dan terlibat langsung dalam kegiatan pembangunan di Desa Bandar Agung bersama BPD. Dan hubungan check and balance antara Kepala Desa bersama anggota BPD.

Dengan berlakunya UndangUndang No 23 Tahun 2014 Tentang Pemerintahan Daerah yang didalamnya mengatur tentang Daerah serta dengan ditetapkannya Undang-Undang Republik Indonesia Nomor 6 Tahun 2014 Tentang Desa maka pedoman pembentukan Badan Permusyawaratan Desa di sesuikan dengan Peraturan Pemerintah tersebut.

\section{Jurnal Sociopolitico}




\section{Faktor penghambat}

Berdasarkan data yang diperoleh di lapangan ada beberapa faktor yang menjadi penghambat kinerja BPD dalam melaksanakan fungsinya, yakni:

\section{a. Partisipasi anggota BPD dalam rapat yang masih kurang}

Badan Permusyawaratan Desa (BPD) mempunyai peran yang penting dalam menetapkan kebijaksanaan dalam menyelenggarakan Pemerintah Desa. Badan Permusyawaratan Desa (BPD) merupakan wadah aspirasi sekaligus merupakan wadah perencana, pelaksanaan dan pengendalian kegiatan masyarakat dan badan-badan lainnya dalam pembangunan desa.

Untuk melaksanakan fungsi Badan Permusyawaratan Desa (BPD) tersebut diatas diperlukan orang-orang yang mampu berkomunikasi dengan baik serta mampu menganalisis aspirasi atau apa yang diinginkan oleh masyarakat yang selanjutnya di koordinasikan dengan Pemerintah Desa.

Stratifikasi atau tingkat pendidikan juga dapat berpengaruh pada keberhasilan penerapan fungsi Badan Permusyawaratan Desa (BPD). Dengan tingginya derajat keilmuan yang dimiliki seseorang maka akan semakin tinggi tingkat analisis terhadap gejala-gejala sosial yang terjadi dalam suatu lingkup masyarakat, namun kenyataannya bahwa tingkat pendidikan pada pengurus BPD masih standar sehingga hal inilah yang menjadi faktor penghambat di dalam merumuskan Peraturan Desa yng akan dibuat.

Eksistensi Badan Permusyawaratan Desa (BPD) sangat dibutuhkan demi jalannya Pembangunan Desa. Sebagai lembaga perwakilan masyarakat desa yang berfungsi untuk menyampaikan aspirasi mereka kepada Pemerintah Desa, anggota Badan Permusyawaratan Desa (BPD) diharapkan memiliki kemampuan intelektual yang tinggi untuk dapat meramu dan menyalurkan aspirasi masyarakat kepada Pemerintah Desa. Tingkat pendidikan dalam kaitannya dengan keberhasilan implementasi fungsi Badan Permusyawaratan Desa Bandar Agung sangat di butuhkan karena mengingat fungsi Badan Permusyawartan Desa Bandar Agung sebagai lembaga parlemen desa, dimana merupakan alat penghubung antara masyarakat dan desa.

Partisipasi BPD dalam rapat pembahasan aspirasi-aspirasi yang disampaikan oleh masyarakat sangatlah penting, karena keaktifan mereka dapat memberikan pengaruh besar tehadap tercapainya aspirasi yang diberikan.

Menurut pernyataan Bapak $\mathrm{M}$. Bisri wakil ketua BPD, yakni :

"Kendala yang biasanya dihadapi oleh BPD sendiri adalah kurangnya partisipasi anggota dalam rapat yang diadakan. Hanya sekitar 50\% anggota yang ikut aktif terlibat dalamrapat."

Dari hasil wawancara tersebut dapat disimpulkan bahwa, salah satu kendala yang dihadapi oleh pihak BPD saat ini adalah kurang berpartisipasinya anggota-anggota BPD dalam rapat yang telah diadakan oleh pihak BPD. Hal tersebut sangat mempengaruhi keefektifan hasil rapat yang ada karena dapat dikatakan bahwa tidak semua dari pihak BPD berperan dan melaksanakan fungsinya secara aktif.

b. Sarana

Dalam melaksanakan tugasnya sebagai BPD sangat dibutuhkan wadah

\section{Jurnal Sociopolitico}


sebagai sekretariat yang digunakan dalam melakukan segala kegiatan yang berkenaan dengan kegiatan BPD mulai perencanaan dan pengadministrasian. Wadah atau tempat berupa kantor sangat dibutuhkan BPD demi terorganisasinya seluruh kegiatan BPD hal ini juga dimaksud untuk memudahkan jalur komunikasi dan koordinasi antara anggota BPD yang lain.

Hal ini di kemukakan Ketua BPD bapak Nureko bahwa :

"Yang menjadi salah satu faktor penghambat dalam pelaksanaan fungsi BPD itu di karenakan belum adanya sekretariat BPD sehingga kita selaku BPD terkadang rapatinternal di kantor desa.

Dari hasil wawncara dan pengamatan saya dilapangan bahwa memang perlu pengadaan sekretariat BPD karena saat ini sekretariat menjadi kendala dalam pelaksanaan peran dan fungsi BPD sehingga tidak ada tempat untuk para anggota BPD untuk berkantor agar peran BPD lebih efektif lagi.

Dan data yang saya dapat dilapangan mengenai belum adanya sarana BPD dalam hal belum adanya kesektariatan BPD untuk berkantor hal ini yang menjadi kendala utama. Masalah Sarana untuk BPD antara lain :

1. Seringnya BPD rapat internal di kantor desa

2. kurang aktifnya anggota BPD dikarenakan tidak adanya kesektariatan.

3. banyaknya arsip-arsip BPD yang hilang dikarenaka tercampurnya data desa di tempat penyimpangan arsip.

Dari uraian diatas itulah yang menyebabkan Ketua BPD mengusulkan pengadaan sekretariat pada saat Musrenbang desa pada januari 2019 dan di terima oleh pemerintah kabupaten dan kecamatan untuk dimasukkan dalam anggaran desa tahun 2019 mengenai pembangunan sekretariat BPD.

\section{Kesimpulan}

1) Membahas dan menyepakati rancangan peraturan desa bersama kepala desa dimana selalu adanya koordinasi yang dilakukan oleh pemerintah desa dalam hal ini kepala desa dengan pihak BPD dalam proses pembahasan dan pembuatan rancangan peraturan desa. Sehingga pada tahun 2019 ada dua perdes yang di buat BPD bersama Kepala Desa yakni perdes Sewa aset dan Perdes APBDes.

2) Menampung dan menyalurkan aspirasi masyarakat, peran BPD dalam hal ini sebagai penampung aspirasi masyarakat telah terlaksana dengan baik sesuai dengan yang diharapakan. Hal tersebut dapat terlihat dari seringnya BPD menjadi wadah masyarakat dalam menyampaikan aspirasi mereka tentang pembangunan desa. Serta terlibatnya BPD dalam hal pembangunan tanpa harus menunggu keluhan dari masyarakat. Ketika ada aspirasi masyarakat yang menjadi kebutuhan Desa Bandar Agung maka BPD langsung melakukan rapat internal bersama anggota BPD yang lainnya dan apakah aspirasi masyarakat dapat di terima di tindaklanjuti atau bagaimana. Setelah itu BPD Menyampaikan hasil rapat internalnya kepada pemerintah desa dalam hal ini Kepala desa mengenai apa yang menjadi masukan dari masyarakat desa Bandar Agung.

\section{Jurnal Sociopolitico}


3) Melakukan pengawasan kinerja kepala desa, terkait dengan fungsi BPD mengenai pengawasan dapat dikatakan telah berjalan secara maksimal dengan melihat tidak adanya kendala yang dihadapi oleh BPD dalam proses pengawasan yang dilakukan tersebut.

\section{Referensi}

Ali, Faried dan Baharuddin, 2013.Pengantar Ilmu Administrasi.Gorontalo:Penerbit PT BIFAD Press.

Agussalim, Andi Gajong 2007. Pemerintahan Daerah (Kajian Politik dan Hukum). Bogor: Ghalia.

Hiddin, Micelle J. 2007 "role theory" in George Ritzer (ed.) TheBlackwell Encyclopedia of Sociology, Blackweel Publishing.

Komaruddin, (1994), eksiklopedia Manajemen edisi kedua, Jakarta : PT. Bumi aksara.

Karim, Abdul Gaffar, 2003. Kompleksitas Persoalan Otonomi Daerahdi Indonesia.Yogyakarta: Pustaka Pelajar.

Lubis, Hari \& Huseini, Martani , (1987 ). Teori organisasi; Suatu Pendekatan Makro.Pusat Antar Ilmu-Ilmu Sosial UI:Jakarta

Ridwan HR, 2006. Hukum Administrasi Negara. Jakarta: RajaGrafindo.

Saleh, Hasrat Arief dkk.2013. Pedoman Penulis Proposal (Usulan Penelitian) \& Skripsi.

Syarifin, Pipin, Jubaedah, Dedah 2005. Hukum Pemerintah Daerah. Bandung: Pustaka Bani Quraisy.
Syarifuddin, Ateng, 1976. Pengaturan Koordinasi Pemerintah Daerah. Bandung: Tarsito.

Sugiyono, 2013. Metode Penelitian Kuantitatif, Kualitatif, dan $R \& D$. Bandung: Afabeta.

Undang-Undang RI Nomor 23 tahun 2014 tentang Pemerintahan Daerah.

Undang-Undang RI Nomor 6 Tahun 2014 tentang Desa. 